Nova Southeastern University

Florida

NOVA SOUTHEASTERN

UNIVERSITY

NSUWorks

Marine \& Environmental Sciences Faculty Articles Department of Marine and Environmental Sciences

4-1-2014

\title{
Historical Reconstruction of Population Density of the Echinoid Diadema antillarum on Florida Keys Shallow Bank-Barrier Reefs
}

Donald L. Kissling

William F. Precht

Dial Cordy and Associates Inc.

Steven Miller

Nova Southeastern University, smiller@nova.edu

Mark Chiappone

Nova Southeastern University, mc191@nova.edu

Find out more information about Nova Southeastern University and the Halmos College of Natural Sciences and Oceanography.

Follow this and additional works at: https://nsuworks.nova.edu/occ_facarticles

Part of the Marine Biology Commons, and the Oceanography and Atmospheric Sciences and Meteorology Commons

\section{NSUWorks Citation}

Donald L. Kissling, William F. Precht, Steven Miller, and Mark Chiappone. 2014. Historical Reconstruction of Population Density of the Echinoid Diadema antillarum on Florida Keys Shallow Bank-Barrier Reefs .Bulletin of Marine Science , (2) : 665 -679.

https://nsuworks.nova.edu/occ_facarticles/734. 


\section{Historical reconstruction of population density of the echinoid Diadema antillarum on Florida Keys shallow bank-barrier reefs}

\author{
${ }^{1}$ Deceased. \\ 2 Dial Cordy and Associates Inc., \\ 7310 Poinciana Court, Miami \\ Lakes, Florida 33014. \\ ${ }^{3}$ Nova Southeastern University, \\ National Coral Reef Institute, \\ Oceanographic Center, 8000 \\ N. Ocean Drive, Dania Beach, \\ Florida 33004. \\ * Corresponding author email: \\ <mc191@nova.edu>.
}

Date Submitted: 4 March, 2013. Date Accepted: 29 August, 2013. Available Online: 29 January, 2014.

\author{
Donald L Kissling ${ }^{1}$ \\ William F Precht ${ }^{2}$ \\ Steven L Miller ${ }^{3}$ \\ Mark Chiappone 3* $^{*}$
}

\begin{abstract}
The 1983-1984 Caribbean-wide mass mortality of the once ubiquitous long-spined sea urchin Diadema antillarum Philippi, 1845, is one of several factors considered responsible for coral reef change throughout the region. Unfortunately, there is a paucity of pre-mortality event density data for D. antillarum in the Florida Keys, making it difficult to determine pre-1983 population density levels. Results from surveys conducted during 1970-1973 in the lower Florida Keys, in shallow $(<12 \mathrm{~m})$ fore reef habitats, yielded relatively abundant and widespread $D$. antillarum densities in qualitative transects at five reefs prior to the 1983-1984 die-off. In quantitative surveys at one reef, Middle Sambo Reef in 1972, up to 7.9 individuals $\mathrm{m}^{-2}$ were recorded using quadrats in high-relief spur and groove habitat. A second mortality event in the Florida Keys, beginning in April 1991, again depressed urchin densities that had begun to recover from the 1983-1984 mass mortality. By 1992, $D$. antillarum densities $\left(<0.01 \mathrm{~m}^{-2}\right)$ were two orders of magnitude lower than pre-die-off estimates (range of $0.07-0.57 \mathrm{~m}^{-2}$ from several spur and groove reefs in the lower Florida Keys) and remained so through 2009. The pre-mortality echinoid density estimates detailed in the Florida Keys provide a baseline to compare with their current population status and should help inform managers about realistic recovery or restoration targets for $D$. antillarum.
\end{abstract}

The 1983-1984 Caribbean-wide mass mortality of the long-spined sea urchin, Diadema antillarum Philippi, 1845, represents one of the more spatially expansive and prolonged disturbances to coral reefs ever documented (Carpenter 1988, Lessios 1988, 2005, Knowlton 2001). Prior to the mass mortality event, D. antillarum attained high densities ( $>20$ individuals $\mathrm{m}^{-2}$ ) on many Caribbean reefs (Lessios 1988), but after the species-specific disease epidemic, densities declined by several orders of magnitude and have largely remained in this state for $>25 \mathrm{yrs}$, with some exceptions (Lessios 2005, Cho and Woodley 2002, Macintyre et al. 2005, Carpenter and Edmunds 2006, Debrot and Nagelkerken 2006, Precht and Aronson 2006, Idjadi et al. 2010). Together with physical impacts from storms, coral disease outbreaks, several 
severe bleaching episodes, and overfishing of herbivorous fishes, the reduction in $D$. antillarum abundance was partly responsible for changes in coral-algal dominance patterns observed over the last 35 yrs (Aronson and Precht 2001a, Gardner et al. 2003, Precht and Miller 2007, Bruno et al. 2009, Schutte et al. 2010).

In the Florida Keys, the few historical data available prior to 1983-1984 indicate that D. antillarum densities were as high as 4-5 individuals $\mathrm{m}^{-2}$ (McPherson 1968, Bauer 1976, 1980), which are lower than reported for some Caribbean reefs in locations such as Jamaica, Puerto Rico, and the US Virgin Islands (Craft 1975, Bauer 1980, Sammarco 1980, 1982, Hay 1984, Carpenter 1986). These historical density values for the Florida Keys, however, are still one to two orders of magnitude greater than more recent observations from 1999-2009 (Chiappone et al. 2002a, 2002b, 2010). A second disease event in the Florida Keys, similar to the first mortality in 1983-1984, occurred 7 yrs later beginning in April 1991 (Forcucci 1994). After slight recovery to $0.30-0.58$ individuals $\mathrm{m}^{-2}$ on shallow fore reefareas, the second mass mortality once again depressed $D$. antillarum densities to $<0.01$ individuals $\mathrm{m}^{-2}$ (Porter and Meier 1992, Forcucci 1994). With the exception of a few shallow-water areas in the Dry Tortugas (Chiappone et al. 2001), large-scale surveys of urchin densities conducted since the 1991 mortality event confirmed the continued pattern of low density and thus relatively slow recovery in the Florida Keys (Chiappone and Sullivan 1997, Chiappone et al. 2002a, 2002b, 2010).

During the late 1980s and early 1990s, a general trend of greater algal cover was reported after the D. antillarum mortality at several Florida Keys offshore reefs (Jaap et al. 1988, 2008, Porter et al. 2002, Dupont et al. 2008). However, identifying clear cause-and-effect relationships between urchin grazing and algal proliferation in the field remains problematic for several reasons. First, specifically designed before-andafter studies were not conducted in the Florida Keys related to urchin decline. It is thus difficult to assess the significance of mortality events with respect to longerterm averages, as ecological time series need to define the boundaries of a natural state, which are rarely available (Phinney et al. 2001, Uthicke et al. 2009). Second, the regional die-off of Acropora corals from white-band disease occurred at roughly the same time, which provided large amounts of dead coral substrate for algal colonization (Dustan and Halas 1987, Jaap et al. 1988, Porter and Meier 1992, Shinn et al. 2000, Aronson and Precht 2001a, 2001b). Third, relatively high densities of herbivorous fishes in the Florida Keys (Bohnsack et al. 1994, Ault et al. 1998) may have ameliorated the effects of the 1983-1984 D. antillarum mass mortality compared to Caribbean reefs with reduced herbivorous fish populations (Hay 1984, Carpenter 1990, Aronson and Precht 2001a, Precht and Miller 2007).

Since the Caribbean-wide D. antillarum mass mortality, some researchers have suggested that population recovery may help to promote coral recruitment and a return to pre-mortality baseline reef conditions (Edmunds and Carpenter 2001, Myhre and Acevedo-Gutiérrez 2007, Idjadi et al. 2010). However, coral diseases and bleaching episodes, as well as a variety of human activities, may counteract any positive influences imparted by increased urchin grazing. Despite the data gaps related to pre-die-off densities, the uncertain impacts of urchin recovery, and uncertainty about other key components of the ecosystem prior to the urchin die-off, there is increasing interest to use management actions such as releasing laboratory-reared urchins (Leber et al. 2008) or translocating urchins from habitats where both settlement and mortality are high (Chiappone et al. 2003, Macia et al. 2007) to restore degraded 


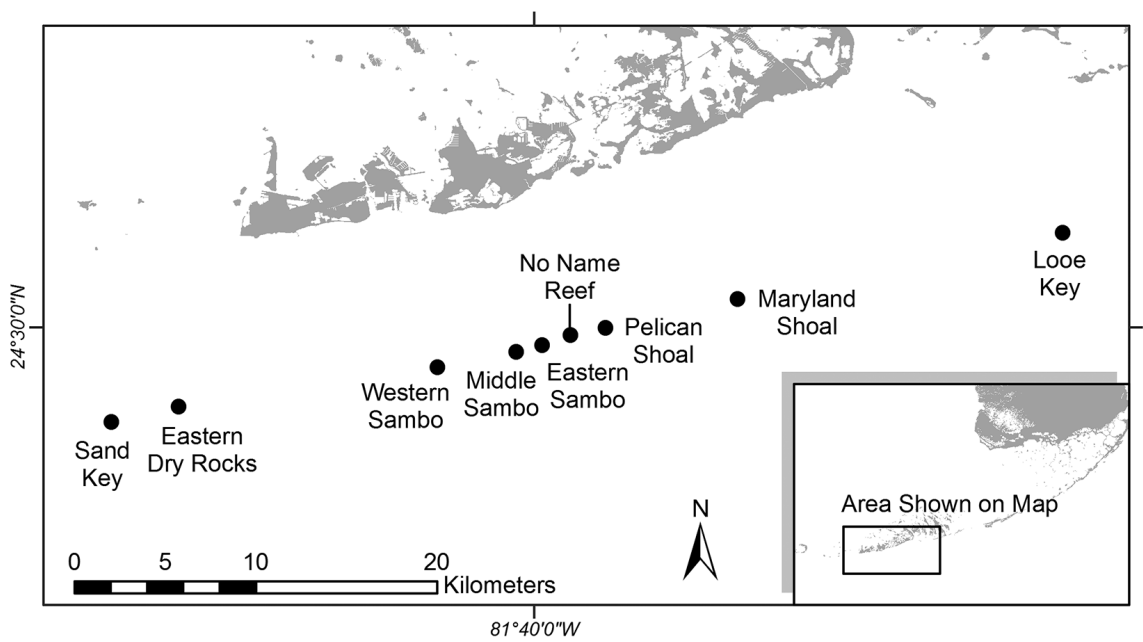

Figure 1. Bank reefs with shallow $(<8 \mathrm{~m})$, high-relief spur and groove topography surveyed during 1970-1973 by one of us (DLK) and resurveyed during 1990-1992 (Forcucci et al. 1994) and 1999-2009 (Chiappone et al. 2002a,b, 2010) in the lower Florida Keys. Forcucci (1994) surveyed Sand Key, Rock Key, Western Sambo, and Middle Sambo only, while Chiappone et al. (2002a, 2002b, 2010) surveyed all nine reefs in the lower Florida Keys during 1999-2009 (see Table 2).

reefs. Such actions necessitate a historical perspective (Rogers and Lorenzen 2009). A largely unpublished National Science Foundation funded project conducted in the 1970s by one of us (DLK) helps to address this data gap. DLK and his students conducted $>190 \mathrm{~d}$ of underwater field studies during 1970-1974 on the hydrological, sedimentological, and ecological elements of coral reefs located from Looe Key westward to Sand Key in the lower Florida Keys region (Fig. 1, Kissling and Taylor 1977). Six of these reefs included $D$. antillarum surveys. The present study aims to summarize the results from these historical surveys related to $D$. antillarum. In addition, we compare these data with periodic and large-scale surveys conducted in a diversity of hard-bottom and coral reef habitats throughout the Florida Keys from 1999 to 2009 (Chiappone et al. 2001, 2002a, 2002b, 2010) that included the same reefs surveyed by Kissling (1977) in the early 1970s.

\section{METHODS}

One of us (DLK) surveyed seven bank-barrier (shelf-margin) reefs with shallow $(<12 \mathrm{~m})$ spur and groove topography in the lower Florida Keys during 1970-1973, encompassing most of the bank reefs in this region of the archipelago (Fig. 1). Three different survey methods, all conducted during daylight hours, were employed to measure the abundance of $D$. antillarum.

Cross-reef Surveys and Coral Rubble Surveys.-First, relative abundance of echinoids was recorded in cross-reef surveys using $10 \times 15$-m quadrats, sequentially every 20-m along north-to-south transects (of variable length) at five reefs described below in the lower Florida Keys. Relative abundance of urchins was estimated as rare $=$ one or few individuals; sparse $=$ many individuals, but dispersed; common $=$ conspicuously numerous and widespread; and abundant = dominant and ubiquitous. 
Additional categories of rare/sparse, sparse/common, and common/abundant were noted. Quadrat results were combined by DLK to provide general descriptions of urchin density for different reef zones at each reef, rather than calculating standard statistical measures.

Looe Key Reef (see Fig. 1 for site locations) was examined along a north-to-south 300-m transect in 1970 and features more than 30 roughly linear spurs up to $120-\mathrm{m}$ in length that deepen seaward from 2 to 8-m depth. A second 90-m transect was examined in 1971 along the back reef rubble and seagrass zones. Maryland Shoal Reef includes 20 irregular, abbreviated spurs, with intervening groove floors ranging from 2 to $6 \mathrm{~m}$ depth; surveys were conducted in 1971 along a north-to-south transect of 330-m in length. Pelican Shoal Reef, surveyed in 1971 along a 240-m transect, displays nearly the same number of abbreviated spurs and grooves as Maryland Shoal, but differs in being bounded on the west by a broad rubble rampart and elongate island extending well north to a sheltered back reef. Eastern Sambo Reef includes approximately 30 spurs and grooves, many as long as $120 \mathrm{~m}$; surveys were conducted along a 300-m transect conducted in 1972. Western Sambo Reef consists of two reefs of unequal size, together forming an especially broad reef buttress comprised of approximately 65 spurs and grooves, many up to $120 \mathrm{~m}$ long and commonly $2-3 \mathrm{~m}$ high. Intervening groove floors range from 2 to $7 \mathrm{~m}$ depth; a 300-m north-to-south transect was surveyed in 1972.

The second survey method used during 1970-1973 focused on urchins sheltered beneath coral rubble. At stations spaced every $20 \mathrm{~m}$ along north-south transects at four reefs (14 stations at Maryland Shoal Reef, 12 stations at Pelican Shoal Reef, 9 stations at Eastern Sambo Reef, and 15 stations at Western Sambo Reef), 20 pieces of coral rubble, at least $15 \times 15 \mathrm{~cm}$, were overturned and all urchins revealed were counted. Total numbers of urchins were reported for Maryland Shoal and Pelican Shoal Reefs, while urchins per station were reported for Eastern and Western Sambo Reefs, allowing means and standard errors to be calculated.

While juvenile and adult urchins were reported separately (also in quadrat surveys at Middle Sambo Reef described below), we acknowledge that because test sizes were not measured this reflects a relatively arbitrary distinction.

Quadrat Surveys at Middle Sambo Reef.-The third survey method involved urchin density counts at Middle Sambo Reef and were conducted during June-July 1972 using seven variously-sized quadrats. The primary focus of the quadrat surveys was identity, number, and spatial distribution of stony coral and octocoral species, but echinoids and other macro-invertebrates were also recoreded. The rationale for the variously-sized quadrats reflects the different habitat types surveyed, but also the fact that marine ecological studies in the 1970s, with scuba diving a relatively new research tool, had not yet developed the more rigorous standards applied today. Means and standard errors were determined. Two quadrats were surveyed in the spur and groove habitat, including a $100-\mathrm{m}^{2}$ quadrat, divided into 25 sub-quadrats, each covering 4- $\mathrm{m}^{2}$, located on the fore reef at 7-m depth that lacked Acropora cervicornis (Lamarck, 1816) and coral rubble. A second 20- $\mathrm{m}^{2}$ quadrat, divided into $102-\mathrm{m}^{2}$ subquadrats, was located at $10-\mathrm{m}$ depth, where the fore reef surface displayed $50-\mathrm{cm}$ of relief and lacked rubble. Three separate censuses were made seaward-to-landward

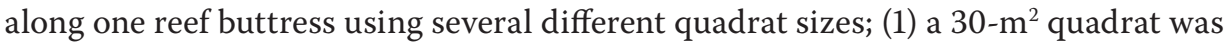
placed on top of the spur at approximately 1.6-2.0 m depth; (2) a quadrat measuring 
$14 \mathrm{~m}$ long by $2 \mathrm{~m}$ high (divided along its long axis into equal halves) was placed on the east-facing wall; and (3) a $25-\mathrm{m}^{2}$ quadrat was placed at the center of the adjacent, sand-blanketed, rubble-strewn groove floor at depths increasing seaward to approximately 4.5-5.0 m depth. Finally, two $100-\mathrm{m}^{2}$ quadrats were located in the seagrass-dominated back reef. The substrate consisted of sand and coral rubble and varying cover (40\%-75\%) by the marine grasses Thalassia testudinum Banks ex König and Syringodium filiforme Kützing. Counts were also made for urchins under rubble and boulders in these two quadrats.

Time Series for the Lower Florida Keys.-Diadema antillarum density data from the present study were combined and analyzed in two ways to compare with results from contemporary studies in the lower Florida Keys that included the same reefs (Forcucci 1994, Chiappone et al. 2002a, 2002b, 2010). First, mean and maximum density values were combined calculated for all sampled reefs in the lower Florida Keys region (Fig. 1) and then were divided into four time intervals, corresponding with the following: (1) the pre-1983-1984 mortality event (the first die-off in the Florida Keys began in July 1983, see Shinn et al. 2000); (2) between the 19831984 mortality event and the beginning of the April 1991 mortality event (Forcucci 1994); (3) after the April 1991 mortality event until 2004 when population recovery was basically non-existent (Chiappone and Sullivan 1997, Chiappone et al. 2002a); and (4) several years thereafter from 2005 to 2009 when the density and size structure of $D$. antillarum began to slightly recover (Chiappone et al. 2010).

Second, results from quadrat surveys during 1972 at Middle Sambo Reef were compared with the mean and maximum densities reported by Forcucci (1994) and Chiappone (2002a, 2002b, 2010) at the same reef. For graphic presentation of density changes, density data were $\log _{2}$-transformed, which is a convenient way to represent doubling or halving of population sizes [e.g., increase of one unit corresponds to a doubling of the untransformed value (Uthicke et al. 2009)]. To accommodate zero densities, a value of 0.01 was added to original densities before transformation.

\section{Results}

Cross-reef Surveys and Coral Rubble Surveys.-At Looe Key Reef during 1970-1971, D. antillarum was reported as common across the hard-ground back reef and the entire spur and groove zone, but only rare/sparse in the seagrass back reef (Table 1). A 90-m transect set across the rubble zone and adjacent seagrass back reef surveyed during August 1971 revealed D. antillarum as consistently rare/sparse at all stations and absent from the seagrass back reef stations.

At Maryland Shoal Reef, D. antillarum was common over most of the rubblerich hard-ground back reef, but was sparse in the seagrass back reef (Table 1). It was likewise common over the truncated spurs and grooves, but sparse on the fore reef. Only total numbers of urchins were reported in the rubble surveys. Six urchins were discovered beneath coral rubble. Five D. antillarum, including three juveniles, were found in the hard-ground back reef, one in a leeward groove, and none from fore reef and seagrass back reef stations.

At Pelican Shoal Reef relative abundance of $D$. antillarum was estimated to be common to abundant within the reef spur-and-groove and hard-ground zones, and rare to absent in the seagrass back reef (Table 1). Only total numbers of urchins were 
Table 1. Relative abundance of Diadema antillarum based on cross-reef surveys at five reefs in the lower Florida Keys during 1970-1971. Transects did not cover all zones at all reefs. Categories include: rare = one or few individuals; sparse $=$ many individuals, but dispersed; common $=$ conspicuously numerous and widespread; and abundant = dominant and ubiquitous. Additional categories of rare/sparse, sparse/common, and common/abundant were noted. $\mathrm{nd}=$ data not available. See Figure 1 for reef locations.

\begin{tabular}{lccccc}
\hline Reef site & Spur and groove & Fore reef $(>8 \mathrm{~m})$ & $\begin{array}{c}\text { Back reef, hard } \\
\text { ground }\end{array}$ & Back reef, rubble & $\begin{array}{c}\text { Back reef, } \\
\text { seagrass }\end{array}$ \\
\hline Looe Key & Common & nd & Common & Rare/sparse & Sparse \\
Maryland Shoal & Common & Sparse & nd & Common & Sparse \\
Pelican Shoal & Common & nd & Common & nd & Rare/absent \\
Eastern Sambo & Sparse/common & Sparse/common & Sparse/common & Sparse/common & Rare/sparse \\
Western Sambo & Sparse/common & Common & Sparse/common & nd & nd \\
\hline
\end{tabular}

reported in the rubble surveys. Twenty-four $D$. antillarum were found under rubble in the spur and groove and hard ground back reef zones. Two urchins were recorded in the seagrass back reef. Adults and juveniles were not distinguished.

At Eastern Sambo Reef, D. antillarum was estimated as sparse to common at all stations surveyed, except the northernmost back reef stations where scattered seagrass cover coincided with rare to sparse urchins (Table 1). Urchin counts for the rubble study totalled $69 \mathrm{D}$. antillarum, including 55 juveniles in the back reef and leeward spur and groove zones. The mean number of adult urchins located under twenty pieces of rubble at each of 12 stations was 2.0 (SE 0.1), with urchins found at only seven of 12 stations. For juvenile urchins, the mean was 4.6 (SE 0.2), with juvenile urchins found at all stations.

Diadema antillarum abundance at Western Sambo Reef was estimated as sparse to common within the hard-ground back reef and spur-and-groove stations and common at three fore reef stations (Table 1). Diadema antillarum encountered beneath rubble diminished from the leeward hard-ground back reef. The average number of urchins was 13.3 (SE 0.3) individuals per 20 boulders in the hard-ground back reef, 7.1 (SE 0.7) individuals per 20 boulders in the leeward sand groove floor, and 1.5 (SE 0.1) individuals per 20 boulders seaward to the outer buttress zone and fore reef, where shelter conferred by coral rubble becomes increasingly scarce. Of the 97 D. antillarum recorded, 65 were juveniles.

Quadrat Surveys at Middle Sambo Reef.-The 100-m² quadrat surveyed at Middle Sambo Reef in the spur and groove zone at 7-m depth contained 251 (density equals $\left.2.5 \mathrm{~m}^{2}\right)$ D. antillarum, including 36 juveniles. Abundance within the $254-\mathrm{m}^{2}$ sub-quadrats ranged from zero to 47 individuals, averaging 2.5 (SE 0.5) $\mathrm{m}^{-2}$.

Within the 20- $\mathrm{m}^{2}$ quadrat (divided into $102-\mathrm{m}^{2}$ sub-quadrats) in the spur and groove zone at 10-m depth, from four to 12 urchins were recorded in the sub-quadrats, totaling $76 \mathrm{D}$. antillarum, for an average density of $3.8 \mathrm{~m}^{-2}$ (Table 2). The average among the sub-quadrats was 3.6 (SE 0.4) $\mathrm{m}^{-2}$.

Among the three separate quadrat censuses conducted along one spur, the $30-\mathrm{m}^{2}$ quadrat placed on the top surface, contained $116 \mathrm{D}$. antillarum, yielding a density of $3.9 \mathrm{~m}^{-2}$ (Table 2). The second quadrat, 14-m long by 2-m high, placed on the eastfacing wall of the same spur contained $110 \mathrm{D}$. antillarum within the bottom 14$\mathrm{m}^{2}$ tier (density of $7.9 \mathrm{~m}^{-2}$ ), and $60 \mathrm{D}$. antillarum in the upper $14-\mathrm{m}^{2}$ tier $\left(4.3 \mathrm{~m}^{-2}\right)$, for an overall mean on the side of the spur of 6.1 individuals $\mathrm{m}^{-2}$. Two of the 170 D. antillarum were juveniles. The third $25-\mathrm{m}^{2}$ quadrat that was placed on the sand 
Table 2. Sampling effort, mean (SE) densities, and maximum densities of Diadema antillarum in quadrat or belt transect surveys on shallow $(<10 \mathrm{~m})$, high-relief spur and groove reefs in the lower Florida Keys during 1970-1974 (Kissling 1977), 1990-1992 (Forcucci 1994), and 1999-2009 (Chiappone et al. 2002a,b, 2010), arranged geographically from east to west (see Fig. 1). Note that the second Diadema mortality event began in April 1991. nd = data not available.

\begin{tabular}{lcccc}
\hline Reef habitat and sample depth $(\mathrm{m})$ & Survey year & $\begin{array}{c}\text { Sample } \\
\text { area }\left(\mathrm{m}^{2}\right)\end{array}$ & $\begin{array}{c}\text { Mean (SE) } \\
\text { no. } \mathrm{m}^{-2}\end{array}$ & Max. no. $\mathrm{m}^{-2}$ \\
\hline
\end{tabular}

\section{Looe Key Reef}

Shallow spur and groove (4.9-8.5)

Shallow spur and groove (4.9-7.9)

Shallow spur and groove (3.0-6.4)

Shallow spur and groove (1.5-6.4)

Shallow spur and groove (3.0-6.4)

Shallow spur and groove (4.3-7.9)

Maryland Shoal

Shallow spur and groove (1.2-6.1)

Shallow spur and groove (1.2-4.6)

Shallow spur and groove (4.6-7.6)

Pelican Shoal

Shallow spur and groove (1.5-4.3)

Shallow spur and groove (1.2-5.2)

Shallow spur and groove (2.4-4.6)

Shallow spur and groove (1.2-6.1)

Shallow spur and groove (1.2-6.1)

No Name Reef

Shallow spur and groove (2.4-5.5)

Shallow spur and groove (3.0-7.0)

Shallow spur and groove (3.0-4.9)

Shallow spur and groove (3.4-4.6)

Eastern Sambo Reef

Shallow spur and groove (1.2-5.2)

Shallow spur and groove (1.5-4.9)

Shallow spur and groove (2.4-5.5)

Shallow spur and groove (1.8-5.2)

Middle Sambo Reef

Shallow spur and groove

Spur top $(1.6-2.0)$

Sand groove (4.5-5.0)

Spur top (7.0)

Spur top (10.0)

Spur side (top/bottom)

Shallow spur and groove (1.0-7.0)

Shallow spur and groove (1.0-7.0)

Shallow spur and groove (1.5-4.9)

Shallow spur and groove (1.8-4.9)

Shallow spur and groove $(1.8-4.0)$

Shallow spur and groove (1.5-4.0)
1999

2000

2005

2007

2008

2009

2007

2008

2009

2001

2005

2007

2008

2009

2001

2007

2008

2009

2001

2007

2008

2009

1972

$\begin{array}{crcc} & 30 & 3.900 & \text { nd } \\ & 28 & 0.700 & \text { nd } \\ & 100 & 2.500 & \text { nd } \\ & 20 & 3.800 & \text { nd } \\ & 28 & 6.100 & \text { nd } \\ 1990 \text { (December) } & 600 & 0.370(0.070) & 0.440 \\ 1991 \text { (November) } & 600 & 0.011(0.002) & 0.013 \\ 2001 & 160 & 0.013(0.008) & 0.050 \\ 2005 & 60 & 0.033(0.019) & 0.067 \\ 2007 & 120 & 0.033(0.018) & 0.133 \\ 2009 & 60 & 0.083(0.042) & 0.200\end{array}$

\section{0}

0

0

0

0

0

120

120

$0.100(0.033) \quad 0.400$

$0.175(0.042) \quad 0.333$

120

0

0

$\begin{array}{cc}0.013(0.013) & 0.050 \\ 0.017(0.017) & 0.067 \\ 0.017(0.017) & 0.067 \\ 0.017(0.017) & 0.133 \\ 0 & 0\end{array}$

0

0.067

0

0.200

0

0.133

0.067

$\begin{array}{ll}0.017(0.011) & 0.067 \\ 0.017(0.011) & 0.067\end{array}$

$\begin{array}{lll}120 & 0.017(0.011) & 0.067 \\ 120 & 0.017(0.011) & 0.067\end{array}$


Table 2. Continued.

\begin{tabular}{|c|c|c|c|c|}
\hline Reef habitat and sample depth (m) & Survey year & $\begin{array}{c}\text { Sample } \\
\text { area }\left(\mathrm{m}^{2}\right)\end{array}$ & $\begin{array}{c}\text { Mean (SE) } \\
\text { no. } \mathrm{m}^{-2}\end{array}$ & Max. no. $\mathrm{m}^{-2}$ \\
\hline \multicolumn{5}{|l|}{ Western Sambo Reef } \\
\hline Shallow spur and groove $(1.0-7.0)$ & 1990 (December) & 600 & $0.575(0.005)$ & 0.580 \\
\hline Shallow spur and groove $(1.0-7.0)$ & 1991 (March-April) & 200 & $0.310(0.098)$ & 0.560 \\
\hline Shallow spur and groove $(1.0-7.0)$ & 1991 (June) & 200 & $0.020(0.004)$ & 0.030 \\
\hline Shallow spur and groove $(1.0-7.0)$ & 1991 (December) & 600 & $0.013(0.005)$ & 0.013 \\
\hline Shallow spur and groove $(1.0-7.0)$ & 1992 (June) & 350 & $0.023(0.014)$ & 0.080 \\
\hline \multicolumn{5}{|l|}{ Western Sambo Reef } \\
\hline Shallow spur and groove $(1.2-4.9)$ & 2005 & 120 & $0.008(0.008)$ & 0.067 \\
\hline Shallow spur and groove (1.5-6.1) & 2007 & 120 & $0.017(0.017)$ & 0.133 \\
\hline Shallow spur and groove $(2.7-5.5)$ & 2008 & 120 & $0.008(0.008)$ & 0.067 \\
\hline Shallow spur and groove $(1.5-4.6)$ & 2009 & 120 & $0.042(0.028)$ & 0.200 \\
\hline \multicolumn{5}{|l|}{ Eastern Dry Rocks } \\
\hline Shallow spur and groove $(1.8-5.8)$ & 2001 & 160 & $0.006(0.006)$ & 0.050 \\
\hline Shallow spur and groove $(1.2-4.9)$ & 2007 & 120 & $0.025(0.018)$ & 0.133 \\
\hline Shallow spur and groove (3.0-6.1) & 2008 & 120 & $0.008(0.008)$ & 0.067 \\
\hline Shallow spur and groove $(1.5-6.7)$ & 2009 & 120 & 0 & 0 \\
\hline \multicolumn{5}{|l|}{ Sand Key Reef } \\
\hline Shallow spur and groove $(1.0-7.0)$ & 1991 (April) & 1,180 & $0.142(0.042)$ & 0.240 \\
\hline Shallow spur and groove $(1.0-7.0)$ & 1991 (October) & 600 & $0.001(0.001)$ & 0.004 \\
\hline Shallow spur and groove $(1.0-7.0)$ & 1991 (November) & 580 & $0.002(0.002)$ & 0.003 \\
\hline Shallow spur and groove $(1.5-5.2)$ & 2001 & 160 & $0.013(0.013)$ & 0.100 \\
\hline Shallow spur and groove $(1.8-4.3)$ & 2007 & 120 & $0.033(0.033)$ & 0.267 \\
\hline Shallow spur and groove $(2.4-5.8)$ & 2008 & 120 & $0.017(0.017)$ & 0.133 \\
\hline Shallow spur and groove $(1.8-5.5)$ & 2009 & 120 & 0 & 0 \\
\hline
\end{tabular}

and rubble groove floor contained 18 D. antillarum, or 0.7 individuals $\mathrm{m}^{-2}$, including two juveniles. Three adult and five juvenile $D$. antillarum were counted among and beneath 193 cobbles and boulders found within the $25-\mathrm{m}^{2}$ quadrat. Within the two $100-\mathrm{m}^{2}$ quadrats that were located in the seagrass back reef, just two D. antillarum were encountered $\left(0.01\right.$ individuals $\left.\mathrm{m}^{-2}\right)$. Urchins that were counted beneath 342 rubble and boulders within the two seagrass quadrats included 15 juvenile $D$. antillarum (0.8 individuals per $\left.\mathrm{m}^{2}\right)$.

Time Series for the Lower Florida Keys.-Using data from the 1970-1973 surveys and published results before and after the 1991 mortality event (Forcucci 1994, Chiappone et al. 2002a, 2002b, 2010), Table 2 summarizes urchin density and size data for the lower Florida Keys bank reefs surveyed during 1970-2009. Density data for several lower Florida Keys reefs (Fig. 2) and for Middle Sambo Reef in particular (Fig. 3) indicate relatively high mean and maximum numbers prior to the first D. antillarum mass mortality event in 1983-1984. After 1984, no urchin surveys, to our knowledge, were conducted in the lower Florida Keys until Forcucci's (1994) surveys began in December 1990, roughly 6 yrs after the first mortality event (Table 3 ). Before the onset of the second D. antillarum mortality in the Florida Keys in April 1991, mean and maximum densities were approximately one-tenth of their pre1983-1984 levels for all reefs combined (Fig. 2) and for Middle Sambo Reef (Fig. 3). 
A.

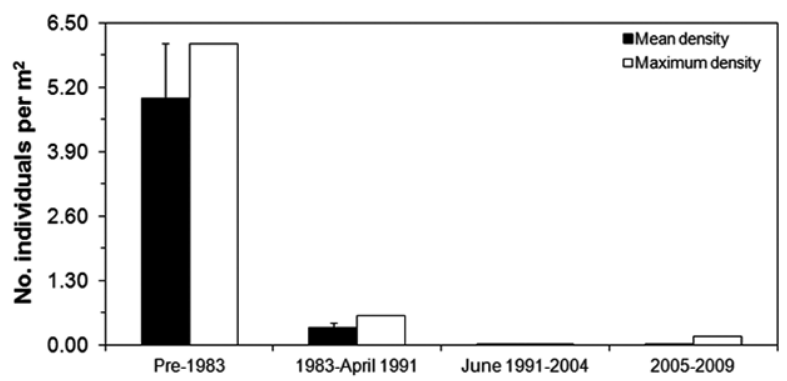

B.

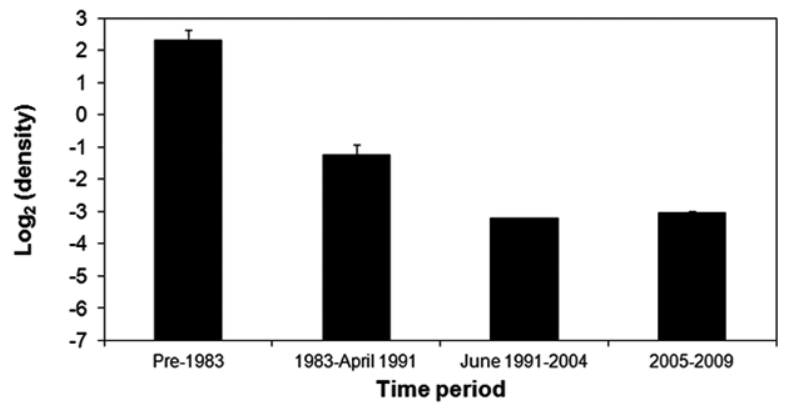

Figure 2. (A) Mean (1 SE) and maximum densities and (B) $\log _{2}$-transformed mean (SE) density of Diadema antillarum on all spur and groove reefs sampled in the lower Florida Keys during 1970-1973, 1990-1991 (Forcucci 1994), and 1999-2009 (Chiappone et al. 2002a, 2002b, 2010). See Table 1 for sample sizes and Table 2 for areas surveyed during each time period.

The onset of the second mortality event depressed mean and maximum densities by two orders of magnitude, a relationship that persisted through 2009 (Fig. 3).

\section{DiscusSION}

Quadrat surveys at Middle Sambo Reef conducted during 1972 indicate that densities of $D$. antillarum were relatively high in the shallow $(<8 \mathrm{~m})$ spur and groove zone $\left(0.7-7.9\right.$ individuals $\left.\mathrm{m}^{-2}\right)$ and on the deeper $(8-10 \mathrm{~m})$ fore reef zone $(2.5-3.9$ individuals $\mathrm{m}^{-2}$ ). We recognize the inconsistency among sampling methodologies related to quadrat sizes and the lack of replication that prevents calculating variance terms. However, the value of these data, even with their constraints, provides a much-needed baseline for the Florida Keys prior to the 1983-1984 D. antillarum mass mortality. Additionally, the qualitative relative abundance surveys carried out between 1970 and 1973 at five lower Florida Keys bank reefs, and the counts of individuals sequestered under rubble along transects at four reefs, further support the notion that $D$. antillarum was common in most reef habitats in the lower Florida Keys during this time period.

It is worth noting that a single $1-\mathrm{m}^{2}$ quadrat studied at $8-\mathrm{m}$ depth on the fore reef of Western Sambo Reef by DLK in July 1973 (Fig. 1), conducted within a thicket of live $A$. cervicornis, contained 17 adult $D$. antillarum. This single $1-\mathrm{m}^{2}$ plot of reef contained more $D$. antillarum individuals than the total number (16 individuals) encountered by Chiappone et al. (2002b) during their 1999 surveys of 80 sites broadly 
A.

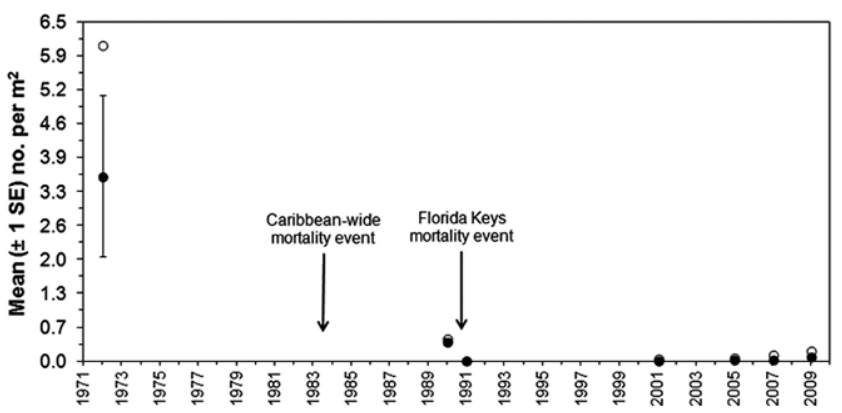

B.

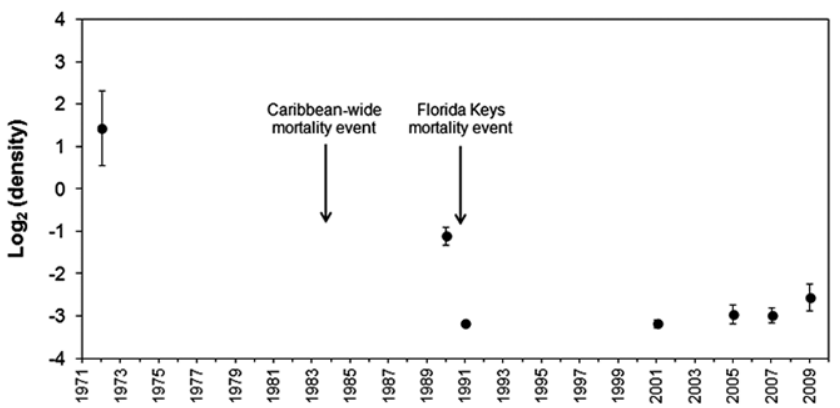

Figure 3. (A) Mean (filled circles, SE) and maximum densities and (B) $\log _{2}$-transformed mean (SE) density of Diadema antillarum in the shallow $(<8 \mathrm{~m}$ depth) spur and groove habitat at Middle Sambo Reef, lower Florida Keys, from 1972 to 2009. See Table 2 for areas surveyed during each time period.

dispersed over the entire Florida Keys offshore reef tract. Without overly ascribing too much importance to a single quadrat, this is further evidence that D. antillarum was a common component of the benthic community on reefs in the lower Florida Keys.

The few available data from two other studies in the Florida Keys prior to the mass mortality event in 1983-1984, where several offshore reefs in the upper Florida Keys were sampled during 1965-1966 (e.g., French Reef; McPherson 1968) and 1977-1978 (e.g., Crocker, Molasses, French, and Elbow Reefs; Bauer 1980), in similar habitats to Middle Sambo Reef, yielded a density range of 0.9-4.5 D. antillarum $\mathrm{m}^{-2}$. Other historical (pre-1983) surveys of D. antillarum in the Florida Keys were either conducted in seagrass habitats (e.g., Randall et al. 1964, Bauer 1976), were qualitative (Voss and Voss 1955, Kier and Grant 1965, Voss 1983, see table 1 in Jackson 1997), or focused on other echinoid species (McPherson 1968). However, these additional observations leave little doubt that $D$. antillarum was ubiquitous and relatively abundant in a broad range of habitats. For example, an image of a cluster of $D$. antillarum on a Florida Keys reef (location unknown) is shown in figure 1 in Randall et al. (1964) and for Molasses Reef by Kier and Grant (1965). Kier and Grant (1961, p. 1) stated in their summary of echinoid distribution off Key Largo that "Diadema antillarum is ubiquitous, living at all observed depths along the shore and on the reef, in large flocks in turtle grass, but not on clean sand." In addition, "Diadema antillarum appeared to be nearly the sole inhabitant of niches within the main body of the reef..." (Kier and 


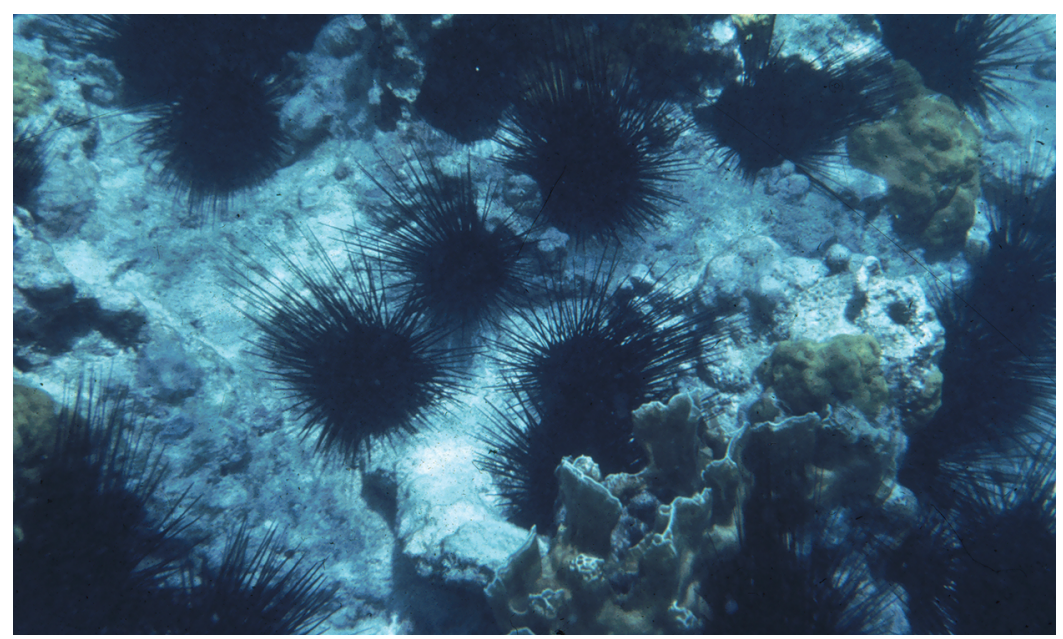

Figure 4. Diadema antillarum at Looe Key on the side of a spur at 3-m depth photographed by the principal author in July 1964.

Grand 1961, p. 60). Diadema antillarum was characterized as "plentiful" by Hudson (1977) in his surveys at Hen and Chickens Reef, a mid-shelf patch reef complex in the upper Florida Keys. One of us (DLK) also took hundreds of photographs in the lower Florida Keys, starting in the 1960s, that documented abundant D. antillarum (e.g., see Fig. 4 from the shallow fore reef at Looe Key).

The slow recovery of this urchin, both regionally and in the Florida Keys (Chiappone et al. 2010), raises the question of what factors currently limit population recovery (Miller et al. 2009, Chiappone et al. 2010). Recent observations of D. antillarum in the Florida Keys indicate that the greatest densities and sizes presently occur on patch reefs, not on shallow bank reefs (Chiappone et al. 2010). Unfortunately, there are no historical urchin data for patch reefs in the Florida Keys, except for a single patch reef site quantitatively surveyed by Forcucci (1994). Moreover, recent (since 2005) surveys indicate that urchin recovery of large adults is much slower on shallow bank reefs compared to patch reefs (Miller et al. 2009). Whether this pattern is due to density-dependent mechanisms, including larval supply (Levitan 1991, Miller et al. 2009), availability of shelter space for larger individuals due to the loss of the labyrinthine thickets of Acropora corals, or other factor(s) such as predation (e.g., Harborne et al. 2009) is uncertain. This uncertainty is highlighted by the fact that abundant juvenile $D$. antillarum have been observed at a number of shallow back reef rubble sites throughout the Florida Keys over the past decade (K Nedimyer, Coral Restoration Foundation, pers comm).

In a review of boom-and-bust cycles in echinoderms (Uthicke et al. 2009), D. antillarum appears to fit the pattern of a species that has experienced rapid population decline, followed by slow and sporadic recovery. This may be indicative of a nonlinear dependency of larval production on adult densities, the low potential for compensatory feedback mechanisms, and an uncoupling of larval and adult ecology (i.e., larvae and adults occupy different habitats) (Levitan 1991). Based on the current rate of recovery in Florida, pre-1983 numbers are not likely to be attained for many decades. As a result of the potential influence $D$. antillarum exerts on limiting algae and enhancing coral recruitment (Sammarco 1980, 1982, Carpenter 1988, Carpenter 
and Edmunds 2006, Myhre and Acevedo-Gutiérrez 2007, Idjadi et al. 2010), restoration of this echinoid through stocking programs has been considered (Aronson and Precht 2006, Halpern et al. 2007, Leber et al. 2008), especially when used in tandem with other actions including the protection of herbivorous fishes. Such demonstration projects performed to date have met with mixed results, tempering initial expectations (Chiappone et al. 2003, Miller and Szmant 2006, Macia et al. 2007). If $D$. antillarum enhancement programs are adopted as a management strategy, the data provided from these baseline surveys conducted in the early 1970s, when combined with results from experimental studies (e.g., Sammarco 1980, Chiappone et al. 2003) and monitored recovery rates (Chiappone et al. 2010), should help define the range of urchin densities targeted for restoration programs in the Florida Keys.

\section{ACKNOWLEDGMENTS}

Original funding for the 1970-1973 surveys was provided to D Kissling by grants from the National Science Foundation (GA-30548), the Link Foundation, and the SUNY Research Foundation. W Aiello, R Bray, V Jindrich, E Kissling, S Landon, C Neuzil, R Peterson, J Purnhagen, R Sherman, and G Taylor served with dedication as field assistants. Funding for the 1999-2009 surveys was provided to S Miller by NOAA's Coral Reef Conservation Program, and NOAA Grant NA96RU-0260 to the National Undersea Research Center at the University of North Carolina-Wilmington. Program management and logistical support to S Miller were provided by the Florida Keys National Marine Sanctuary, NOAA's National Undersea Research Center at UNCW, Biscayne National Park and Dry Tortugas National Park, RSMASUniversity of Miami (J Ault and S Smith), and NOAA/NMFS (J Bohnsack). Permission to conduct research in the Florida Keys was granted under Sanctuary Permits FKNMS-074-98 and FKNMS-2009-002 and National Park Service Permit BISC-2005-SCI-0039. We dedicate this paper to the memory of Brian Keller for his always-insightful scientific advice and encouragement that helped to shape our research programs. We also acknowledge the recent passing of Don L Kissling, the senior author of this manuscript. His pioneering geological and ecological studies performed in the late 1960s and early 1970s in the Florida Keys represent a unique data set that in addition to urchins includes corals, gorgonians, and other components of the reef community. Comments by three anonymous reviewers substantially improved the paper.

\section{Literature Cited}

Aronson RB, Precht WF. 2001a. Evolutionary paleoecology of Caribbean coral reefs. In: Allmon WD, Bottjer DJ, editors. Evolutionary paleoecology: the ecological context of macroevolutionary change. New York: Columbia University Press. p. 171-233.

Aronson RB, Precht WF. 2001b. White-band disease and the changing face of Caribbean coral reefs. Hydrobiologia. 460:25-38. http://dx.doi.org/10.1023/A:1013103928980

Aronson RB, Precht WF. 2006. Conservation, precaution, and Caribbean reefs. Coral Reefs. 25:441-450. http://dx.doi.org/10.100//s00338-006-0122-9

Ault J5, Bohnsack JA, Meester GA. 1998. A retrospective (1979-1996) multispecies assessment of coral reef fish stocks in the Florida Keys. Fish Bull US. 96:395-414.

Bauer JC. 1976. Growth, aggregation and maturation in the echinoid Diadema antillarum. Bull Mar Sci. 26:273-277.

Bauer JC. 1980. Observations on geographic variations in population density of the echinoid Diadema antillarum within the western north Atlantic. Bull Mar Sci. 30:509-515.

Bohnsack JA, Harper DE, McClellan DB. 1994. Fisheries trends from Monroe County, Florida. Bull Mar Sci. 54:982-1018. 
Bruno JF, Sweatman H, Precht WF, Selig ER, Schutte VGW. 2009. Assessing evidence of phase shifts from coral to macroalgal dominance on coral reefs. Ecology. 90:1478-1484. PMid:19569362. http://dx.doi.org/10.1890/08-1781.1

Carpenter RC. 1986. Partitioning herbivory and its effects on coral reef algal communities. Ecol Monogr. 56:345-363. http://dx.doi.org/10.2307/1942551

Carpenter RC. 1988. Mass-mortality of a Caribbean sea urchin: immediate effects on community metabolism and other herbivores. Proc Natl Acad Sci USA. 85:511-514. PMid:16593907. PMCid:PMC279580. http://dx.doi.org/10.1073/pnas.85.2.511

Carpenter RC. 1990. Mass mortaility of Diadema antillarum. 1. Long term effects on sea urchin population-dynamics and coral reef algal communities. Mar Biol. 104:67-77. http://dx.doi. org/10.1007/BF01313159

Carpenter RC, Edmunds PJ. 2006. Local and regional scale recovery of Diadema promotes recruitment of scleractinian corals. Ecol Lett. 9:271-280. PMid:16958892. http://dx.doi. org/10.1111/j.1461-0248.2005.00866.X

Chiappone M, Miller SL, Swanson DW, Ault JS, Smith SG. 2001. Comparatively high densities of the long-spined sea urchin in the Dry Tortugas, Florida. Coral Reefs. 20:137-138. http:// dx.doi.org/10.1007/s003380100162

Chiappone M, Rutten LM, Swanson DW, Miller SL. 2010. Population status of the urchin Diadema antillarum in the Florida Keys 25 years after the Caribbean mass mortality. Proc 11th Intl Coral Reef Symp. p. 706-710.

Chiappone M, Sullivan KM. 1997. Rapid assessment of reefs in the Florida Keys: results from a synoptic survey. Proc 8th Intl Coral Reef Symp. 2:1509-1514.

Chiappone M, Swanson DW, Miller SL. 2002a. Density, spatial distribution and size structure of urchins in Florida Keys coral reef and hard-bottom habitats. Mar Ecol Prog Ser. 235:117126. http://dx.doi.org/10.3354/meps235117

Chiappone M, Swanson DW, Miller SL, Smith SG. 2002b. Large-scale surveys on the Florida reef tract indicate poor recovery of the long-spined sea urchin Diadema antillarum. Coral Reefs. 21:155-159.

Chiappone M, Swanson DW, Miller SL. 2003. One-year response of Florida Keys patch reef communities to translocation of long-spined sea urchins (Diadema antillarum). Key Largo, Florida: University of North Carolina-Wilmington. Available from: www.floridakeys.noaa. gov/research_monitoring/reports/diadema/dia_app1.pdf via the Internet. Accessed 25 July, 2013.

Cho LL, Woodley JD. 2002. Recovery of reefs at Discovery Bay, Jamaica and the role of Diadema antillarum. Proc 9th Intl Coral Reef Symp. 1:331-338.

Craft LL. 1975. Aspects of the biology of the crab Percnon gibbesi (Milne Edwards) and its commensal association with the sea urchin Diadema antillarum. MS thesis, University of Puerto Rico, Mayagüez, Puerto Rico. 200 p.

Debrot AO, Nagelkerken I. 2006. Recovery of the long-spined sea urchin Diadema antillarum in Curacao (Netherlands Antilles) linked to lagoonal and wave sheltered shallow rocky habitats. Bull Mar Sci. 79:415-424.

Dupont JM, Jaap WC, Hallock P. 2008. A retrospective analysis and comparative study of stony coral assemblages in Biscayne National Park, FL (1977-2000). Carib J Sci. 44:334-344.

Dustan P, Halas JC. 1987. Changes in the reef-coral community of Carysfort Reef, Key Largo, Florida: 1974 to 1982. Coral Reefs. 6:91-106. http://dx.doi.org/10.1007/BF00301378

Edmunds PJ, Carpenter RC. 2001. Recovery of Diadema antillarum reduces macroalgal cover and increases abundance of juvenile corals on a Caribbean reef. Proc Natl Acad Sci USA. 98:5067-5071. PMid:11274358. PMCid:PMC33164. http://dx.đol.org/10.1073/ pnas.071524598

Forcucci D. 1994. Population, density and recruitment and 1991 mortality event of Diadema antillarum in the Florida Keys. Bull Mar Sci. 54:917-928. 
Gardner TA, Cote IM, Gill JA, Grant A, Watkinson AR. 2003. Long-term region-wide declines in Caribbean corals. Science. 301:958-960. PMid:12869698. http://dx.doi.org/10.1126/ science. 1086050

Halpern BS, Silliman BR, Olden JD, Bruno JP, Bertness MD. 2007. Incorporating positive interactions in aquatic restoration and conservation. Front Ecol Environ. 5:153-160. http:// dx.doi.org/10.1890/1540-9295(2007)5[153:IPIIAR]2.0.CO;2

Harborne, AR, Renaud PG, Tyler EHM, Mumby PJ. 2009. Reduced density of the herbivorous urchin Diadema antillarum inside a Caribbean marine reserve linked to increased predation pressure by fishes. Coral Reefs. 28:783-791. http://dx.doi.org/10.1007/s00338-009-0516-6

Hay ME. 1984. Patterns of fish and urchin grazing on Caribbean coral reets: are previous results typical? Ecology. 65:446-454. http://dx.doi.org/10.2307/1941407

Hudson JH. 1977. Long-term bioerosion rates on a Florida reef: a new method. Proc 3rd Intl Coral Reef Symp. 2:491-498.

Idjadi JA, Haring RN, Precht WF. 2010. Recovery of the sea urchin Diadema antillarum promotes scleractinian coral growth on shallow Jamaican reefs. Mar Ecol Prog Ser. 403:91100. http://dx.doi.org/10.3354/meps08463

Jaap WC, Halas JC, Muller RG. 1988. Community dynamics of stony corals (Milleporina and Scleractinia) at Key Largo National Marine Sanctuary, Florida, during 1981-1986. Proc 6th Intl Coral Reef Symp. 2:237-243.

Jaap WC, Szmant A, Jaap K, Dupont J, Clarke R, Somerfield P, Ault JS, Bohnsack JA, Kellison SG, Kellison GT. 2008. A perspective on the biology of Florida Keys coral reefs. Chapter 3 In: Riegl BM, Dodge RE, editors. Coral reefs of the USA. Netherlands: Springer. p. 75-125. http://dx.doi.org/10.1007/978-1-4020-6847-8_3

Jackson JBC. 1997. Reefs since Columbus. Corai Reefs. 16:S23-S32. http://dx.doi.org/10.1007/ s003380050238

Kier PM, Grant RE. 1965. Echinoid distribution and habits, Key Largo Coral Reef Preserve, Florida. Smithsonian Misc Coll. 149(6):1-68.

Kissling DL. 1977. Coral reefs in the lower Florida Keys: a preliminary report. In: Multer HG, editor. Field guide to some carbonate rock environments: Florida Keys and western Bahamas. Dubuque, Iowa: New Edition. p. 209-215.

Kissling DL, Taylor GT. 1977. Habitat factors for reef dwelling ophiuroids in the Florida Keys. Proc 3rd Intl Coral Reef Symp. 1:225-231.

Knowlton N. 2001 Sea urchin recovery from mass mortality: new hope for Caribbean coral reefs? Proc Natl Acad Sci USA. 98:4822-4824. PMid:11320228. PMCid:PMC33118. http:// dx.doi.org/10.1073/pnas.091107198

Leber K, Adams A, Main K, Vaughan D, Moe M, Nedimyer K. 2008. Examining the efficacy of Diadema antillarum enhancement for restoration of coral reefs in the Florida Keys. Mote Marine Laboratory Technical Report 1258, Sarasota, FL. 21 p.

Lessios HA. 1988. Mass mortality of Diadema antillarum in the Caribbean: what have we learned? Ann Rev Ecol Syst. 19:371-393.

Lessios HA. 2005. Diadema antillarum populations in Panama twenty years following mass mortality. Coral Reefs. 24:125-127. http://dx.doi.org/10.1007/s00338-004-0443-5

Levitan DR. 1991. Influence of body size and population density on fertilization success and reproductive output in a free-spawning invertebrate. Biol Bull. 181:261-268. http://dx.doi. org/10.2307/1542097

Macia S, Robinson MP, Nalevanko A. 2007. Experimental dispersal of recovering Diadema antillarum increases grazing intensity and reduces macroalgal abundance on a coral reef. Mar Ecol Prog Ser. 348:173-182. http://dx.doi.org/10.3354/meps06962

Macintyre IG, Glynn PW, Hinds F. 2005. Evidence of the role of Diadema antillarum in the promotion of coral settlement and survivorship. Coral Reefs. 24:273. http://dx.doi. org/10.1007/s00338-005-0492-4

McPherson BF. 1968. Contributions to the biology of the sea urchin Eucidaris tribuloides (Lamarck). Bull Mar Sci. 18:400-443. 
Miller MW, Szmant AM. 2006. Lessons learned from experimental key-species restoration. In: Precht WF, editor. Coral reef restoration handbook. The rehabilitation of an ecosystem under siege. Boca Raton, Florida: CRC Press. p. 219-233.

Miller MW, Kramer KL, Williams SM, Johnston L, Szmant AM. 2009. Assessment of current rates of Diadema antillarum larval settlement. Coral Reefs. 28:511-515. http://dx.doi. org/10.1007/s00338-008-0458-4

Myhre S, Acevedo-Gutiérrez A. 2007. Recovery of sea urchin Diadema antillarum populations is correlated to increased coral and reduced macroalgal cover. Mar Ecol Prog Ser. 329:205-210. http://dx.doi.org/10.3354/meps329205

Phinney JT, Muller-Karger F, Dustan P, Sobel ). 2001. Using remote sensing to reassess the mass mortality of Diadema antillarum 1983-1984. Conserv Biol. 15:885-891. http://dx.doi. org/10.1046/j.1523-1739.2001.015004885.x

Porter JW, Kosmynin V, Patterson KL, Porter KG, Jaap WC, Wheaton JL, Hackett K, Lybolt L, Tsokos CP, Yanev G, et al. 2002. Detection of coral reef change by the coral reef monitoring project. In: Porter JW, Porter KG, editors. The Everglades, Florida Bay, and coral reefs of the Florida Keys. Boca Raton, Florida: CRC Press. p. 749-769.

Porter JW, Meier OW. 1992. Quantification of loss and change in Floridian reef coral populations. Am Zool. 32:625-640.

Precht WF, Aronson RB. 2006. Death and resurrection of Caribbean coral reefs: a palaeoecological approach. In: Côté IM, Reynolds JD, editors. Coral reef conservation. Cambridge University Press, Cambridge, UK. p. 40-77. http://dx.doi.org/10.1017/ CBO9780511804472.004

Precht WF, Miller SL. 2007. Ecological shifts along the Florida Reef Tract: the past as a key to the future. In: Aronson RB, editor. Geological approaches to coral reef ecology. Springer, NY. p. 237-312.

Randall JE, Schroeder RE, Starck WA. 1964. Notes on the biology of the echinoid Diadema antillarum. Carib J Sci. 4:421-433.

Rogers A, Lorenzen K. 2009. Recovery of Diadema antillarum and the potential of for active rebuilding measures: modeling population dynamics. Proc 11th Intl Coral Reef Symp. Session 20:956-960.

Sammarco PW. 1980. Diadema and its relationship to coral spat mortality: grazing, competition, and biological disturbance. J Exp Mar Biol Ecol. 45:245-272. http://dx.doi. org/10.1016/0022-0981(80)90061-1

Sammarco PW. 1982. Echinoid grazing as a structuring force in coral communities: whole reef manipulations. J Exp Mar Biol Ecol. 61:31-55. http://dx.doi. org/10.1016/0022-0981(82)90020-X

Schutte VGW, Selig ER, Bruno JF. 2010. Regional spatiotemporal trends in Caribbean coral reef benthic communities. Mar Ecol Prog Ser. 402:115-122. http://dx.doi.org/10.3354/ meps08438

Shinn EA, Smith GW, Prospero JM, Betzer P, Hayes ML, Garrison V, Barber RT. 2000. African dust and the demise of Caribbean coral reefs. Geophys Res Let. 27:3029-3032. http:// dx.doi.org/10.1029/2000GL011599

Uthicke S, Schaeffelke B, Byrne M. 2009. A boom-bust phylum? Ecological and evolutionary consequences of density variations in echinoderms. Ecol Monogr. 79:3-24. http://dx.doi. org/10.1890/07-2136.1

Voss GL. 1983. An environmental assessment of the John Pennekamp Coral Reef State Park and the Key Largo National Marine Sanctuary. NOAA Tech Mem. NOS NCCOS CCMA 161, Silver Spring, Maryland.

Voss GL, Voss NA. 1955. An ecological survey of Soldier Key, Biscayne Bay, Florida. Bull Mar Sci Gulf Carib. 5:203-229.

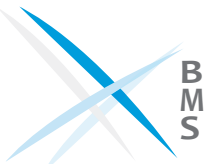

